\title{
LITERATURA DE CORDEL: VEÍCULO DE COMUNICAÇÃO E EDUCAÇÃO EM SAÚDE ${ }^{1}$ \\ “TWINE” LITERATURE: A VEHICLE FOR COMMUNICATION AND EDUCATION IN HEALTH LA LITERATURA DE CORDEL: VEHÍCULO DE COMUNICACIÓN Y EDUCACIÓN EN SALÚD
}

\author{
Lorita Marlena Freitag Pagliuca², Paula Marciana Pinheiro Oliveira ${ }^{3}$, Cristiana Brasil de Almeida Rebouças', Marli \\ Teresinha Gimeniz Galvão ${ }^{5}$
}

${ }^{1}$ Trabalho elaborado no Projeto Laboratório de Comunicação em Saúde (LabCom_Saúde) da Universidade Federal do Ceará (UFC) e financiado pelo Conselho Nacional de Desenvolvimento Científico e Tecnológico (CNPq).

${ }^{2}$ Enfermeira. Doutora em Enfermagem. Professora Titular do Departamento de Enfermagem da UFC. Pesquisadora do CNPq. Ceará, Brasil.

${ }^{3}$ Acadêmica de Enfermagem do $8^{\circ}$ semestre da UFC. Bolsista CNPq. Integrante do Projeto LabCom Saúde. Ceará, Brasil.

${ }^{4}$ Mestreem Enfermagem Clínico-Cirúrgica. Doutorandado ProgramadePós-Graduação emEnfermagem da ŪFC. Bolsista Coordenação de Aperfeiçoamento de Pessoal de Nível Superior. Ceará, Brasil.

${ }^{5}$ Enfermeira. Doutora em Enfermagem. Professora Adjunto do Departamento de Enfermagem da UFC. Pesquisadora do CNPq. Ceará, Brasil.

PALAVRAS-CHAVE: Literatura. Comunicação em saúde. Educação. Síndrome de Imunodeficiência Adquirida.
RESUMO: Literatura de cordel são folhetos impressos, com ilustrações xilográficas. Neste estudo objetivou-se analisar as mensagens e linguagens nos folhetos que abordam o tema Vírus da Imunodeficiência Humana e a Síndrome da Imunodeficiência Adquirida. Trata-se de um estudo exploratório-descritivo do tipo documental, precedido de busca sistemática de cordéis, de agosto a novembro de 2006. Dos folhetos pesquisados, três abordavam a Síndrome da Imunodeficiência Adquirida. A análise de conteúdo direcionou a construção de cinco categorias: origem, ação, conseqüências e transmissão do vírus; mulher x infecção; situação em que não há contaminação pelo vírus; prevenção; e literatura de cordel como meio de comunicação em saúde. Os cordelistas apresentaram conteúdo informativo satisfatório para produzir no imaginário dos indivíduos um alerta favorável à inserção de medidas de prevenção e controle da Síndrome da Imunodeficiência Adquirida. O cordel revelou-se ferramenta de comunicação para promoção à saúde.
KEYWORDS: Literature. Health Communication. Education. Acquired Immunodeficiency índrome.
ABSTRACT: Twine literature, as it is known in Brazil, is composed of printed booklets, illustrated with woodcuts. This study aimed to analyze the messages and language used in such booklets about the Human Immunodeficiency Virusand AcquiredImmunodeficiency Syndrome. Anexploratory-descriptivedocumentary study was carried out, preceded by a systematic search of "twines" between August and November of 2006. Three of those examined addressed the Acquired Immunodeficiency Syndrome. Content analysis resulted in the construction of five categories: origin, action, consequences and transmission of virus; woman $\mathrm{x}$ infection; situations in which contamination by the virus does not occur; prevention; and "twine" literature as a communication means in health. The "twine" authors presented satisfactory information content to produce an alert in the individuals' imaginary that favors the insertion of measures for the prevention and control of Acquired Immunodeficiency Virus. This literature revealed to be a communication tool for health promotion.

RESUMEN: La literatura de cordel son cuadernillos impresos, con ilustraciones xilográficas. El objetivo de este estudio fue el de analizar los mensajes y el lenguaje empleado en los cuadernillos que tratan del tema: Virus de la Inmunodeficiencia Humana y el Síndrome de Inmunodeficiencia Adquirida. Es un estudio exploratoriodescriptivo del tipo documental, precedido de una búsqueda sistemática de cordeles, la cual fue realizada de agosto a noviembre de 2006. De los cuadernillos investigados, tres trataban sobre el Síndrome de Inmunodeficiencia Adquirida. El análisis de contenido dirigió la construcción de cinco categorías: origen, acción, consecuencias y transmisión del virus; mujer x infección; situación en que no hay contaminación por el virus; prevención; la literatura de cordel como medio de comunicación en salud. Los cordeles presentaron un contenido informativo satisfactorio para producir en el imaginario de los individuos un alerta favorable a la inserción de medidas de prevención y control del Síndrome de Inmunodeficiencia Adquirida. El cordel se mostró una herramienta de comunicación para promoción de la salud.
Lorita Marlena Freitag Pagliuca

Endereço: Av.Trajano de Medeiros, 2840 60.180-660 - Dunas, Fortaleza, CE, Brasil. E-mail: pagliuca@ufc.br
Artigo original: Pesquisa

Recebido em: 16 de abril de 2007 Aprovação final: 08 de outubro de 2007 


\section{INTRODUÇÃO}

Literatura de cordel são folhetos escritos e impressos, com ilustrações nas capas na forma de xilogravuras feitas com canivetes, estiletes (gravuras feitas em madeiras) e desenhos espontâneos e rudes. ${ }^{1} \mathrm{O}$ cordel foi assim denominado porque em Portugal era exposto em barbantes para vendas em locais públicos.

SurgidonaPenínsulaIbérica, mencionadomeiode comunicação, tão conhecido por muitos, foitrazido para o Brasil por colonizadores europeus em fins do século XIX.Porlongoperíodo, antesdoaparecimentodo rádio, ficou conhecido como único meio de comunicação nas zonas rurais. A literatura de cordel é caracterizada pela sua impressão gráfica e circula em folhetos impressos desde a segunda metade do século XIX. Tais folhetosforam trazidos para o Estado do Ceará no início de século XX, e sobressaíram, particularmente, no município de Juazeiro do Norte. Em Fortaleza, só passaram a existir na época da oligarquia de Nogueira Accioly. ${ }^{2}$

A princípio o cordel era específico de pessoas analfabetas e semi-analfabetas, mas atualmente é também escrito por pessoas que sabem ler e escrever. Como mostram determinados autores, a literatura de cordel sempre esteve presente na cultura brasileira, não é algo do passado. ${ }^{1}$ Em alguns estados, como Pernambuco, Ceará, Alagoas, Paraíba e Bahia, o cordel ainda é bem acessível e faz muito sucesso entre a população. Desde os princípios, o cordel obteve sucesso, não apenas em virtudedo menor preço, mas, também, pelotom humorístico dado às histórias contadas e pela possibilidade de retratar fatos da vida cotidiana da cidade ou da região. Segundo observado, o principal enfoque dos versos e estrofes são assuntos de disputas, vida de cangaceiros, atos de heroísmo, entre outros. ${ }^{2}$

Conforme algumas informações, a literatura de cordel foi utilizada até para auxiliar as pessoas na leitura. Segundo consta, uma criança aprendeu a ler com sua avó por meio desses folhetos. Em pouco mais de um mês estava a ler cordéis na "bodega" do avô com muita desenvoltura e como "centro das atenções". A literatura de cordel também é empregada na vida estudantil, como retrata a experiência do poeta Manoel Monteiro. O mesmo cita leituras de cordéis como estratégia de ensino, mostrando-se interessante às crianças, jovense adultosao utilizaressaliteratura. Inclui-se aindao prazereo interesse pela leitura, estimulando, com isso, o hábito de ler. ${ }^{2}$

De acordo com o observado, existem cordéis que abordam temas na área da saúde, como: diabetes, drogas, aids, cigarro, idoso, dengue, raiva, além de outros. Entre estes, a Acquired Immune Deficiency Syndrome
(AIDS), por ser considerada doença epidêmica em âmbito mundial e por apresentar impacto significativo na vida das populações acometidas, é tema de interesse no presente estudo. No Brasil, até junho de 2006, foram notificados 433.067 casos de AIDS até junho de 2006. Destes, 62,3\% (269.910 casos) se concentram na região Sudeste, $17,9 \%$ (77.639 casos) na região Sul, $11 \%$ (47.751 casos) no Nordeste, $5,6 \%$ (24.086 casos) no Centro-Oeste e 3,2\% (13.681 casos) no Norte. Das diversas regiões, a Nordeste é a terceira em número de casos e mostra persistente aumento da doença. Até este período, o Ceará acumulou 8.019 casos. $^{3}$

O Nordeste é uma das regiões mais pobres do país e apresenta os piores níveis de desenvolvimento social e econômico e um dos mais baixos Índices de Desenvolvimento Humano(IDH). Noúltimo censo, a região metropolitana de Fortaleza mostrou um IDH de $0,767 .{ }^{4} \mathrm{O}$ comportamento da epidemia de AIDS nessa região reflete este quadro de desigualdade social.

Em decorrência das adversidades climáticas e dos problemassocioeconômicosepolíticos, o Nordestevem apresentando elevado fluxo migratório para as capitais, onde os indivíduos se alojam, sobretudo, nas periferias. Nesses locais, formam bolsões de miséria, aumentando a vulnerabilidade ao Human Imunodeficiency Virus (HIV) e a outras Doenças Sexualmente Transmissíveis(DSTs), em virtude das condições desfavoráveis a que estão expostos. Associado a isto, observa-se um complexo mosaico composto por crenças, valores e concepções sobre sexualidade que forma verdadeiros obstáculos à prevenção das DSTs e AIDS junto a esta população. Desse modo, como se percebe, as estratégias utilizadas em nível de atenção primária ainda estão sendo pouco efetivas na redução da vulnerabilidade ao HIV/AIDS. ${ }^{5}$

Diante da importância do tema, é, pois, necessário conhecer a AIDS e o HIV, no intuito de educar a população e conseqüentemente prepará-lapara ter uma vida mais saudável. Para isto, no entanto, urge retratar alguns tópicos a respeito deste conteúdo para que as pessoas que tenham acesso a estes folhetos possam ler, aprender e fixar as orientações neles contidas.

Comoevidenciado, todos osindivíduos com vida sexual ativa estão em risco de contaminação pelo HIV. Entre os principais fatores de risco mencionam-se as relações sexuais desprotegidas e o uso compartilhado de seringas e agulhas contaminadas. ${ }^{5}$

Em face da intensa penetração da literatura de cordel, particularmente nas classes populares, impõe-se um estudo documental destes folhetos, com vistas a se averiguar a existência de erros neles existentes pas- 
síveis de comprometer sua mensagem, como também se o conteúdo contempla informações básicas acerca da doença. Além disso, é imprescindível saber se a produção dos cordelistas está sendo transmitida de forma compreensível à população. Para facilitar essa compreensão, tanto os indivíduos de baixa escolaridade e analfabetos que estiverem aprendendo a ler, como também a população já alfabetizada que tiver acesso a seu conteúdo, devem dispor de informação atualizada e sustentada pela literatura científica.

Neste sentido, por ser a enfermagem uma profissão interessada na prevenção de doenças e promoção da saúde, faz-se necessário o trabalho integrado entre enfermeiros e cordelistas no intuito de educar adequadamente a população leitora destes folhetos de forma a contribuir para a devida apreensão da informação.

Diante, portanto, da relevância do assunto, objetivou-se analisar as mensagens transmitidas e a linguagem adotada nos folhetos que abordem o tema HIV/AIDS.

\section{METODOLOGIA}

Estudo exploratório-descritivo do tipo documental. A pesquisa documental baseia-se em documentos originais ainda não utilizados em nenhum trabalho científico.

O estudo foi realizado mediante a busca sistemática de folhetos de cordel disponíveis em cordões (varais) em cinco praças públicas do centro de Fortaleza - CE, nos meses de agosto a novembro de 2006 e durante a Bienal Internacional do Livro do Ceará (realização cultural onde o livro é assunto principal), ocorrida em outubro de 2006. Como critério de seleção, optou-se por temas que retratassem a saúde, exclusivamente a temática HIV/AIDS. Das praças visitadas, em três localizaram-se cordéis que se adequavam ao tema proposto.

Os cordéis foram analisados a partir do método de análise de conteúdo de Bardin, ${ }^{6}$ a se realizar em três momentos: a pré-análise, a exploração do material e o tratamento dos resultados (a inferência e a interpretação), tendo como suporte a literatura científica sobre a temática. A pré-análise trata da organização do material coletado no intuito de fundamentar a interpretação dos dados. Durante esta fase, procedeu-se à leitura dos folhetos e a partir daíforam encontrados os indicadores (temas). A exploração do material é a etapa mais demorada e exaustiva. Nessa fase, realizam-se as codificações nas quais os dados são transformados em unidades que permitam descrições das características relacionadas ao conteúdo dos folhetos. A codificação compreende a escolha das unidades de registro (recorte), a seleção de regras de contagem (enumeração) e a escolha de categorias (classificação e agregação).

Quanto ao tratamento dos resultados, consistiu nas inferências feitas sobre os dados, e sua interpretação foi obtida mediante relação dos dados encontrados e a fundamentação teórica acerca da temática HIV/AIDS.

\section{RESULTADOS E DISCUSSÃO}

Foram encontrados três folhetos que retrataram a temática AIDS. Para familiarizar os leitores com os cordelistas do presente estudo, teceremos breves comentários sobre eles. Manoel Monteiro nasceu em Bezerro, Pernambuco, em fevereiro de 1937. Importante cordelista brasileiro em atividade, com uma produção densa e diversificada, abordando temas de toda a área da atividade humana e membro da Academia Brasileira de Literatura de Cordel. Em razão da qualidade de sua produção, a literatura de cordel está sendo indicada para a grade escolar de várias cidades brasileiras. ${ }^{4-7}$ Outro cordelista foi Elizeu de Souza Paulino, nascido em 1964 em Pacatuba no Ceará, com vários folhetos publicados. Atualmente representa os poetas populares na Banca Nacional do cordel, na praça dos Correios, no centro de Fortaleza. ${ }^{8}$ Os demais autores foram Guaipuan Vieira e Gerardo Carvalho (Pardal). O primeiro é Membro da Academia Municipalista de Letras do Estado do Ceará e Presidente do Centro Cultural dos Cordelistas do Nordeste (Cecordel), e o segundo é poeta cordelista, graduado em Filosofia Pura, especializado em Tecnologia Educacional em nível de pós-graduação lato sensu e estudante de Comunicação Social. Em 1994 destacou-se entre os doze primeiros colocados do Prêmio de Literatura de Cordel do Ceará, promovido pelo Governo do Estado do Ceará, com 120 concorrentes. $^{9}$

Os folhetos tiveram como temas, autores e conteúdo, respectivamente: Quem não usa camisinha, não pode dizer que ama, de Manoel Monteiro, que retrata doenças sexualmente transmissíveis; prevenção do HIV e educação em saúde (uso da camisinha); origem do vírus e conseqüência da infecção; grupos de risco; aborto, sinônimo de inconseqüência; educação no pré-natal; teste e exame utilizado no diagnóstico da AIDS; situações em que não há a contaminação pelo vírus; câncer (CA) de mama e colo uterino (prevenção e exames); Previnase contra a AIDS, de Elizeu de Souza Paulino, que aborda a contaminação, transmissão; prevenção e 
prostituição x HIV/AIDS; e Previna-se contra a AIDS: ela mata, de Guaipuan Vieira e Gerardo Carvalho (Pardal), que discorre a respeito da ação do vírus; prevenção; gestante x HIV/AIDS e situação em que o vírus não contamina.

Como mencionado, as informações contidas nos folhetos foram apreciadas de acordo com o método de análise de conteúdo. Conforme proposto, os versos foram transcritos para facilitar a categorização. Dessa forma, constituíram as cinco categorias identificadas após a realização das etapas do método, entre elas: 1) origem, ação, conseqüências e trans- missão do HIV; 2) mulher e a contaminação pelo HIV; 3) situação em que não há contaminação pelo vírus; 4) prevenção; e 5) literatura de cordel como meio de comunicação em saúde.

Na primeira categoria, Origem é conceituada como algo primitivo, original, sem imitações, causa determinante, procedência. Ação é o ato de agir, atuar, desenvolver atividades, é a própria execução destes. Conseqüência é a dedução, conclusão e o resultado de algo e, por sua vez, a Transmissão é o contágio de pessoa a pessoa, é o transmitir, propagar, contaminar algo ou alguém (Quadro 1).

Quadro 1 - Origem, ação, conseqüências e transmissão do HIV. Fortaleza - CE, 2006.

\begin{tabular}{|c|c|c|c|}
\hline \multirow{2}{*}{ Categoria } & \multicolumn{3}{|c|}{ Cordelistas } \\
\hline & Monteiro $(2005)^{7}$ & Paulino (199-) ${ }^{8}$ & Vieira e Carvalho $(1996)^{9}$ \\
\hline Origem & $\begin{array}{l}\text { Até hoje não se sabe } \\
\text { De onde veio esse mal } \\
\text { Se nasceu entre o contato } \\
\text { Do homem com o animal } \\
\text { Se das drogas injetáveis } \\
\text { Sangue impuro ou coito anal. }{ }^{7: 5}\end{array}$ & & \\
\hline Ação & $\begin{array}{l}\text { O HIV, segundo } \\
\text { Estabelece a ciência } \\
\text { Vem a ser o VÍRUS DA } \\
\text { IMUNODEFICIÊNCIA } \\
\text { HUMANA que mina e leva } \\
\text { O organismo a falência. } .^{7: 5} \\
\text { Pois deixa o corpo em aberto } \\
\text { Para invasões deletérias... } \\
\ldots \text {..E perversas bactérias } \\
\text { Que transformam males simples } \\
\text { Em enfermidades sérias. }{ }^{7: 5} \\
\text {...Porque todo organismo } \\
\text { Sem as defesas permite } \\
\text { Que o HIV domine } \\
\text { E a AIDS se precipite. } .^{7: 6}\end{array}$ & & $\begin{array}{l} \\
\text { O vírus HIV } \\
\text { É um vírus resistente } \\
\text { Que invade o organismo } \\
\text { Planta do mal a semente } \\
\text { Destrói as nossas defesas...9:2 }\end{array}$ \\
\hline Conseqüências & $\begin{array}{l}\text { Sendo HIV, cuidado! } \\
\text { Pois uma tênue anemia } \\
\text { Vai duma gripe banal } \\
\text { À uma pneumonia } \\
\text { Chegando à tuberculose } \\
\text { Que aos pulmões avaria. }{ }^{*} \text { : } 6 \\
\text { Trazendo a herpes consigo } \\
\text { Pré-câncer, câncer e sarcoma, } \\
\text { Verrugas que se transformam } \\
\text { Nos terríveis condilomas... } \\
\\
\text { Falta de ar, febre e tosse } \\
\text { Corrimento vaginal, } \\
\text { Diarréia permanente, } \\
\text { Perturbação visual, } \\
\text { Dores pelo baixo- ventre, } \\
\text { Sono fora do normal. } 7: 7\end{array}$ & & \\
\hline
\end{tabular}




\begin{tabular}{|c|c|c|c|}
\hline Transmissão & $\begin{array}{l}\text { Tomando droga injetável } \\
\text { Evite seringa usada, } \\
\text { Se a primeira pessoa } \\
\text { A deixou contaminada } \\
\text { Quem vir usá-la em seguida } \\
\text { Pode ser prejudicada. }{ }^{7: 17}\end{array}$ & $\begin{array}{l}\text { Com o sexo se pega AIDS } \\
\text { Feito fora da razão } \\
\text { A droga aumentou o risco } \\
\text { Nesta proporção.... } \\
\text { Q:2 } \\
\text { Quem tem AIDS sempre diz } \\
\text { Pelas quais contaminou } \\
\text { Geralmente foi no sexo } \\
\text { Ou foi droga que injetou... }\end{array}$ & $\begin{array}{l}\text { Também é fonte de risco } \\
\text { O sexo quando é oral } \\
\text { Ferimentos como sêmen } \\
\text { Pode contrair o mal...9:4 } \\
\text { Dizendo que alguns maridos } \\
\text { De outras trazem os ais doídos } \\
\text { Pra suas esposas diletas. } .^{9: 5}\end{array}$ \\
\hline
\end{tabular}

*O conteúdo deste verso transita em ação e conseqüência.

Quanto à origem do vírus, Monteiro a menciona. Dar-se-á particular importância para tal abordagem, pois as descobertas sobre o HIV encontradas poderão contribuir decisivamente para se desenvolver a vacina contra o vírus.

A AIDS é uma doença resultante do estágio avançado da infecção pelo HIV. Sua veiculação ocorre por contato com sangue e líquidos corporais contaminados e é caracterizada pela diminuição da imunidade mediante destruição das células T. O diagnóstico laboratorial é estabelecido pela presença de anticorpos anti-HIV no sangue, realizado pelo exame de Western blot. Também se utilizam como marcadores da doença a avaliação da quantidade de linfócitos T CD4 + por milímetro cúbico de sangue e a dosagem da carga viral, observando-se neste a presença de Ácido Ribonucleico (RNA) viral no sangue. ${ }^{10}$

Dois cordelistas descreveram a ação do vírus, cujo conteúdo é fundamental quando se quer retratar o HIV, afinal, a forma como ele age no organismo pode ser uma curiosidade para grande parte da população, principalmente para aquelas já contaminadas. Além disso, serve de alerta para indivíduos que estão desenvolvendo sintomas indicativos de doenças oportunistas.

Com relação às conseqüências, estas são citadas apenas por Monteiro. Mas é relevante falar sobre elas, já que muitas pessoas, ao tomarem conhecimento do que o HIV pode causar, poderão ter mais cuidado no controle da doença, promovendo autocuidado, situação desejável entre os indivíduos com vistas a se manterem saudáveis.

Monteiro parece bastante perspicaz ao descrever as conseqüências, pois além de ser o único a relatá-las usou imaginação e saga para descrever as implicações da infecção pelo HIV. Entretanto, algumas conseqüências descritas são inadequadas no contexto do HIV/AIDS. Entre elas: "Menstruação persistente, ou espassada o bastante [...]; Vaginites, uretrites, [...] a clamydia trachomatis, transmite-se pelo contato, e o mais chato é falar, de um bicho chamado chato". ${ }^{7:-8}$ Estes sintomas são de doenças transmitidas pelo contato sexual, mas não são necessariamente conseqüências do HIV. Elas indicam que o indivíduo está se relacionando sexualmente sem uso de proteção adequada, o que pode levá-lo a contrair o HIV.

Para finalizar, nesta categoria, a transmissão foi retratada pelos cordelistas. Este assunto é fundamental no contexto da saúde de um modo geral, pois mostra como o HIV contamina. Por meio deste conhecimento, é possível constatar a melhor maneira de se evitar o contágio e possivelmente diminuir as taxas de HIV na população.

Percebeu-se, contudo, um erro em um folheto a respeito da transmissão. Vieira e Carvalho mencionam o seguinte: "[...] ferimentos como o sêmen [...]”. 9:4 Sabe-se, portanto, que sêmen não é ferimento, mas uma célula conduzida pela secreção sexual masculina.

Quadro 2 - Mulher e a contaminação pelo HIV. Fortaleza - CE, 2006.

\begin{tabular}{|c|c|c|}
\hline \multicolumn{3}{|c|}{ Cordelistas } \\
\hline Monteiro $(2005)^{7}$ & Paulino (199-) $)^{8}$ & Vieira e Carvalho (1996) ${ }^{9}$ \\
\hline Soropositiva grávida & Mulheres prostituídas & \\
\hline Precisa está consciente & Sem nenhuma precaução & A mãe sendo infectada \\
\hline Que o bebê corre o risco.... ${ }^{7: 14}$ & Fazem o sexo desregrado & E uma gravidez gerar \\
\hline & Tornando a AIDS um vilão....8: 6 & O seu filhinho inocente \\
\hline Nesse caso a gestação & & Quando ao mundo for chegar \\
\hline Requer acompanhamento & Meninas com doze anos & Carregará esta cruz \\
\hline Um pré-natal cuidadoso & Sem a mínima proteção & Que só mesmo o Bom Jesus \\
\hline Pois já tem medicamento & Procuram as áreas turísticas & Com sua luz pra lhe salvar. ${ }^{9: 4}$ \\
\hline Pra durante a gravidez & Teêm no sexo o ganha pão & \\
\hline E depois do nascimento. ${ }^{7:} 14$ & Com isto o risco aumentou....8: 8 & \\
\hline
\end{tabular}


No Quadro 2 apresenta-se a categoria 2, cujos conteúdos retratam a mulher e o HIV. Os cordelistas abordaram a Transmissão Vertical (TV), ou seja, a possibilidade de a mãe contaminar seu filho durante e após a gestação. Eles alertam para os riscos decorrentes da infecção para a criança e a relação do HIV com a prostituição infantil.

No Ceará, as crianças nascidas de mães portadoras do HIV somam $83,6 \%$ das crianças menores de 13 anos contaminadas no estado. Uma das causas que contribuem para a TV nessa região tem sido atribuída à omissão de testes para o HIV no pré-natal. ${ }^{11}$

Aotratar o assunto, Monteiro, Vieira e Carvalho referiram a questão da mulher em idade reprodutiva com o risco da transmissão vertical. Já Paulino enfatizou a questão da prostituição em crianças e adolescentes além do risco de contágio do HIV por meio do sexo sem precaução, em decorrência de problemas sociais como a pobreza e falta de oportunidade de trabalho que atingem grande parte da população. Segundo se depreende, os cordelistas abordaram a mulher no contexto da soropositividade para o HIV, sugerindo a atenção feminina para este tema. Com efeito, estudos demonstram a inserção crescente de mulheres contaminadas pelo HIV..$^{3-12}$ Aquelas com pouca escolaridade e precárias condições econômicas têm sido apontadas como as mais vulneráveis ao $\mathrm{HIV}$, muitas vezes por dificuldades de negociarem com seus parceiros o uso efetivo do preservativo. ${ }^{13}$
Ademais, os cordelistas chamam a atenção diretamente para as mulheres nos conteúdos retratados. Provavelmente, no intuito de alertá-las para a necessidade de se protegerem diante das conseqüências advindas do HIV.

De acordo com as recomendações de pesquisadores, os profissionais de saúde devem atuar de forma a prevenir a contaminação do HIV para o filho com medidas profiláticas, uma vez que o uso adequado dos anti-retrovirais reduz os casos de TV para níveis aproximados de $2 \%{ }^{14}$

É interessante salientar a importância da educação em saúde ao incentivar o uso de preservativos às mulheres como também aos seus companheiros, pois a relação sexual é sempre passível de favorecer a transmissão do HIV.

Outro assunto abordado em um dos cordéis, cujo autor é Paulino ${ }^{8}$, foi a questão da prostituição de crianças e adolescentes que contribui para a contaminação e disseminação da doença. Quanto à prostituição de adolescentes citada pelo mesmo autor, muitas o fazem para ter algum recurso e conseguirem driblar a fome e a miséria, situação comumente vivenciada pela grande maioria. Neste contexto de vulnerabilidade a que estão expostas, é indispensável à atuação multiprofissional ao promover o cuidado da saúde, sobretudo ao reforçar o uso de preservativos. Desse modo, pode-se alertar para a prevenção e a promoção da saúde da população.

Quadro 3 - Situação em que não há contaminação pelo vírus. Fortaleza - CE, 2006.

\begin{tabular}{|c|c|}
\hline \multicolumn{2}{|c|}{ Cordelistas } \\
\hline Monteiro $(2005)^{7}$ & Vieira e Carvalho $(1996)^{9}$ \\
\hline $\begin{array}{l}\text { A AIDS não se transmite } \\
\text { No assento sanitário, } \\
\text { No aperto de mão, no beijo, } \\
\text { No abraço solidário, } \\
\text { Nos contatos sociais } \\
\text { Nem no convívio diário. } 7: 16 \\
\text {...AIDS não marca presença, } \\
\text { Nem talher, bandeja, copo... } \\
\text {...Que só sexo, sangue e droga } \\
\text { Viabilizam a doença.7: } 16\end{array}$ & $\begin{array}{l}\text {...AIDS não pega não } \\
\text { Só com beijos e carícias } \\
\text { Mesmo na boca beijando....9: } 6 \\
\text { Por suor, lágrima ou saliva... } \\
\text {...Nem por tossida ou espirrado.... 9: } 6 \\
\text {...Nem num trocar de vestido } \\
\text { Mas se trocar de marido } \\
\text { Eu não Ihe garanto Não!!! }{ }^{9: 7} \\
\text { E mesmo se for picado } \\
\text { Por algum inseto danado } \\
\text { AIDS não pega de fato. } 9: 7 \\
\text { Nem mesmo nos vestuários } \\
\text { Nos banheiros ou piscinas... } 9: 7 \\
\text { Em cadeira, banco e assento } \\
\text { Não se viu em nenhum momento } \\
\text { Alguém ser contaminado. } 9: 8\end{array}$ \\
\hline
\end{tabular}


Como mostra o Quadro 3, quando se retratou a situação em que não existe contaminação pelo vírus, delimitaram-se os casos em que o vírus não contamina e nem há risco de transmissão.

Em virtude da desinformação, muitos são os questionamentos a respeito da transmissão do vírus. De modo geral, as pessoas, e até mesmo os familiares e amigos, temem aproximar-se, abraçar, beijar soropositivos com receio da contaminação. Portanto, é fundamental destacar as reais formas de contaminação, quais sejam: por relações sexuais sem o uso constante do preservativo, pelo sangue, sobretudo pelo uso compartilhado de seringas entre usuários de drogas, e por transmissão da mãe contaminada para o filho.

O folheto mostrou corretamente as questões $\mathrm{da}$ contaminação e não contaminação. Isto é educação em saúde, e vale a pena divulgar tais trabalhos, afinal, desse modo, a população estará mais informada e, assim, os tabus e dúvidas mais freqüentes poderão ser esclarecidos.
Em face, porém, das constantes dúvidas, é importante esclarecer como ocorre esta contaminação. O processo é o seguinte: o HIV ataca as células $\mathrm{T}$ auxiliares que carregam o antígeno $\mathrm{CD} 4+$, ao percorrerem a corrente sangüínea; a partir do RNA viral, o HIV copia seu material genético de maneira reversa; o Ácido Desoxirribonucleico (DNA) viral entra no núcleo da célula, onde se incorpora ao DNA da célula do hospedeiro e é transcrito em quantidade maior de RNA viral; a célula do hospedeiro se reproduz, duplicando seu DNA viral e passando-o para suas células-filhas recém-formadas; enzimas virais, conhecidas como proteases, arrumam nas partículas virais, seu RNA; as partículas virais se deslocam para a periferia da célula do hospedeiro, onde emergem brotamentos virais que seguem para infectar outras células. Portanto, a infecção pelo HIV destrói células CD4+, outras células imunes e células neurogliais. ${ }^{10}$

Quadro 4 - Prevenção do vírus HIV. Fortaleza - CE, 2006.

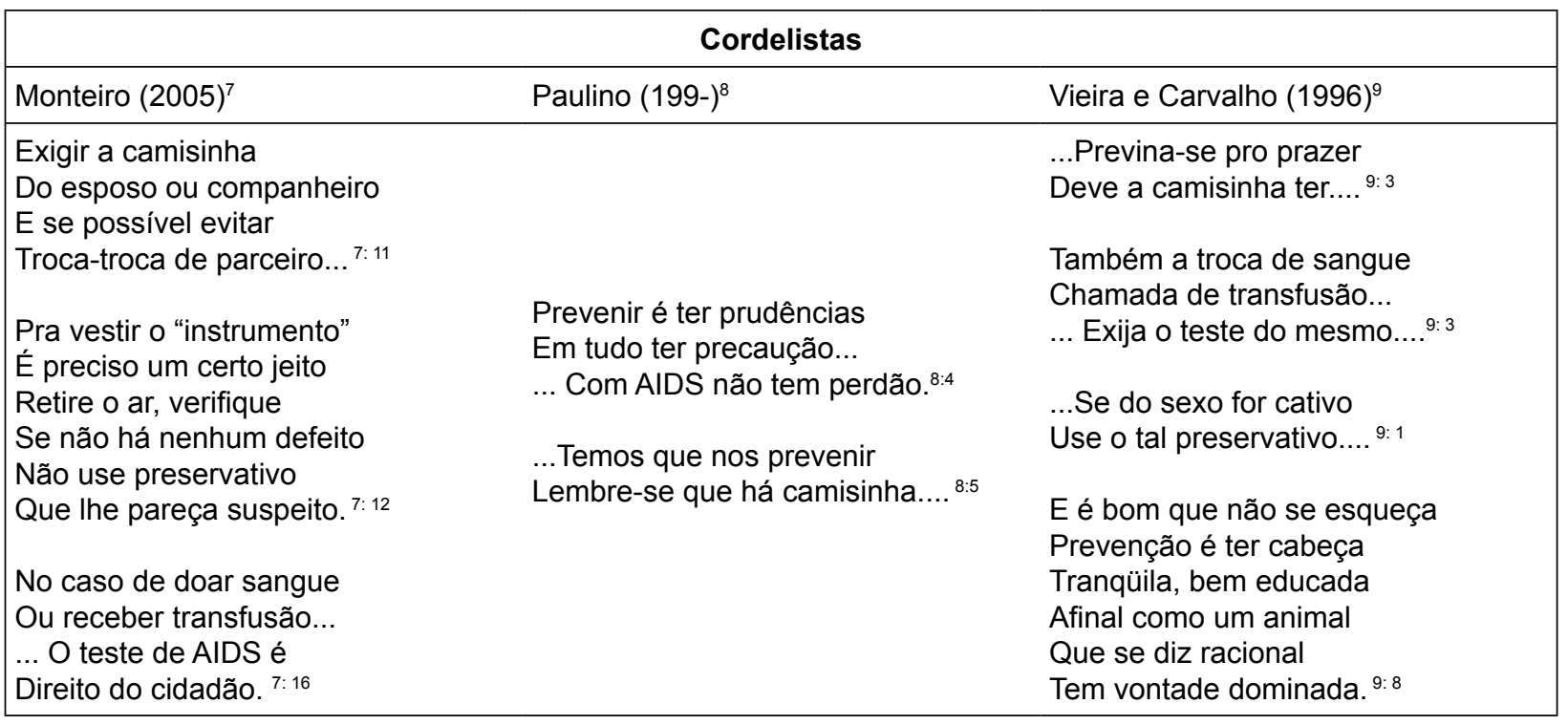

A categoria prevenção, citada no Quadro 4, significa ação ou efeito de prevenir. Prevenir é tomar medidas com vistas a antecipar algo provável de acontecer. É aconselhar, avisar antecipadamente e preparar-se com antecedência. Prevenir no contexto da AIDS é aconselhar, informar a população sobre as medidas para evitar que aconteça tal episódio, ou seja, eliminar qualquer possibilidade de contaminação com o vírus do HIV. ${ }^{5}$

Determinados estudos apontam o aumento de pessoas infectadas pelo HIV e o drama de viver na situação de contaminados, mesmo com a disponibilidade de medicamentos gratuitos, que tem garantido melhor qualidade de vida entre os contaminados. Por isso, para garantir não apenas a ampliação da sobrevida das pessoas, mas, também, melhor qualidade de vida, é importante que todos os profissionais da saúde e educação desenvolvam maneiras de ajudar as pessoas e sensibilizá-las a respeito da contaminação e transmissão do HIV. ${ }^{13}$ 
A complexidade das estratégias que envolvem a prevenção da AIDS deveria mudar o foco de prevenção do comportamento propriamente para os ambientes culturais das populações onde esse comportamento acontece e para as regras sociais que se or- ganizam. Nesta perspectiva, o cordel com conteúdo informativo sobre HIV/AIDS poderá ser utilizado como estratégia educativa para divulgar diversas informações sobre a infecção pelo HIV, a exemplo da origem, ocorrência e formas de contaminação.

Quadro 5 - Literatura de cordel como meio de comunicação em saúde. Fortaleza - CE, 2006.

\begin{tabular}{|c|c|c|}
\hline \multicolumn{3}{|c|}{ Cordelistas } \\
\hline Monteiro $(2005)^{7}$ & Paulino (199-) $)^{8}$ & Vieira e Carvalho $(1996)^{9}$ \\
\hline $\begin{array}{l}\text { Por isso a informação } \\
\text { Tem sido nosso estandarte } \\
\text { Trabalhando em poesia } \\
\text { Popular a nossa arte } \\
\text { Adverte aos que se amam } \\
\text { Pra fazerem sua parte. } \\
\\
\text { A: 18 } \\
\text { A AIDS vem progredindo } \\
\text { Com passadas de gigante } \\
\text { Para reverter as cifras } \\
\text { Dessa estatística alarmante } \\
\text { A informação parece } \\
\text { O antídoto mais importante. }\end{array}$ & $\begin{array}{l}\text { Informações de proveitos } \\
\text { Nos traz à literatura } \\
\text { Os versos quando legítimos } \\
\text { Sem dúvida nos assegura } \\
\text { Leituras com bons conceitos } \\
\text { Poeta tem seus preceitos } \\
\text { Formando as boas posturas. } 8: 6 \\
\text {...Amor feito com prudências } \\
\text { Fiz algumas advertências } \\
\text { Em muito nos preveniu. } 8: 8 \\
\text {... Fiz o que tinha que fazer } \\
\text { Mostrei a AIDS de perto } \\
\text { O modo de se prever } \\
\text { Peço atenção dos leitores } \\
\text { Jovens mulheres ou senhores } \\
\text { Gravem pra não esquecer. } 8: 8\end{array}$ & $\begin{array}{l}\text { Por isso caro leitor } \\
\text { Neste meu verso matuto } \\
\text { Um conselho de amigo } \\
\text { De caboclo bem astuto } \\
\text { Se do sexo for cativo } \\
\text { Use o tal preservativo } \\
\text { Ou terá a família em luto.9: } 1\end{array}$ \\
\hline
\end{tabular}

Nesta última categoria, referida no Quadro 5, procurou-se refletir acerca da literatura de cordel como meio importante de divulgação e educação em saúde. Os cordelistas, finalizando o repertório comunicativo nos folhetos, enfatizam a literatura de cordel como meio de educare prevenir a populaçãoacercadadoença. Segundo sedepreende, eles procuraram retratare afirmaravalidez da comunicação registrada nos folhetos, pois nestes a AIDS é divulgada com uma arte comunicativa.

Porcomunicação compreende-se tornaro mesmo assunto igualmente compreensível entre duas ou mais pessoas, dialogar, conversar pondo o mesmo objeto em discussão. O processo de comunicação se constitui instrumento básico da experiência entre os seres humanos e a sociedade, além de ser uma necessidade básica sem a qual a existência da humanidade seria impossível. ${ }^{15}$

Nos folhetos existe uma forma de comunicação verbal, a escrita. Quando retratam a AIDS, os cordelistas conseguem abordar o tema, listando os principais pontos e advertindo as pessoas e comunidades. Apesar de ocorreremerrosao relacionaremalgumasinformaçõesequivocadas sobre a AIDS, como citado, eles conseguiram abordar devidamente a problemática utilizando outras fontes de informação conhecidas pela população regional.
Contudo, embora essas informações possam ser absorvidas por letrados e não letrados, é relevante a leitura e a orientação de maneira correta. Ao apresentar um folheto para um iniciante naleitura ou semiletrado, quando ele aprender a ler, certamente captará, concomitante à leitura, instruções de maneira ajustada, e o aprendizado tornar-se-á assim bem mais válido. Por ser o cordel uma estratégia de divulgação e de amplo acesso às comunidades, principalmente, do Nordeste brasileiro, quanto mais exatas forem suas mensagens mais seguro será o aprendizado.

Conforme observado, os cordéis incluem ainda a descrição dos exames específicos para detecção do HIV, como os testes Elisa e Western Blot de exames sanguíneos que confirmam e identificam a presença de anticorpos, anti-HIV.Outrosexamescomoode mamaePapanicolau também foram comentados nosfolhetos para prevenção do câncer de mama e de colo uterino, respectivamente. Estas informações foram descritas apenas por Monteiro, porém não foram abordadas nesta pesquisa, a qual delimitou-se somente à temática da AIDS.

Como mencionado, alguns erros foram encontrados nos folhetos deste mesmo autor, a exemplo de: "Cancro mole e cancro duro são tumores cancerosos 
[...]". 7:3 Mas, cancro mole e duro são doenças sexualmente transmissíveis e, não, tumores cancerosos.

\section{CONSIDERAÇÕES FINAIS}

Segundo se pôde perceber, os folhetos de cordel retrataram a AIDS, utilizando em seus versos e estrofes as diferentes maneiras de apresentá-la à sociedade. Resumidamente, os autores cordelistas apresentaram um conteúdo informativosatisfatório para produzir no imaginário dos indivíduos um alerta favorável à inserção de medidas de prevenção e controle da AIDS na população.

As informações analisadas bem como a linguagem utilizada nos cordéis, foram consideradas válidas para serem utilizadas junto à população por fornecerem uma visão geral sobre a doença, além de ser um conteúdo acessível a toda população.

Assim, a enfermagem pode tomar como ferramenta alternativa de comunicação tais mensagens de promoção à saúde mediante o uso de folhetos de cordel. Esses materiais podem ser mais facilmente encontrados na região Nordeste do país. Em Fortaleza, especificamente, a literatura de cordel é muito utilizada e está disponível à venda por preços acessíveis a toda população em bancas e praças públicas da cidade.

Por meio destes folhetos, é possível se promover oficinas com vistas a despertar curiosidade e atenção da população como um todo, afinal são versos rimados que conseguem cativar, e, ao mesmo tempo, divertireeducar a comunidade, tanto crianças como adultos e idosos.

\section{REFERÊNCIAS}

1 Kawall LE. Cordel: o jornal do sertão [on line] [acesso em 2006 Out 30]. Disponível em: http://www.bibvirt. futuro.usp.br

2 Lima AV. Acorda cordel na sala de aula. Fortaleza (CE): Tupynamquim Ed.; 2006.

3 Ministério da Saúde (BR), Secretaria de Vigilância à Saúde, Programa Nacional de Controle e Prevenção de
DST/AIDS. Semanas epidemiológicas: $1^{\mathrm{a}}-26^{\mathrm{a}}$ de 2006. Bol. Epidemiol.: AIDS DST. 2006 Jan-Jun; 3 (1): 7.

4 Programa das Nações Unidas para o Desenvolvimento (BR). Tabelas de ranking do IDH-M. Brasília (DF): PNUD Brasil; [acesso em 2007 Fev 26]. Disponível em: http://www.pnud.org.br/atlas/tabelas/index.php

5 Kerr-Pontes LRS, Gonzalez F, Kendall C, Leão EM, TávoraFR, CaminhaI, et al.Prevention of HIV infection among migrant population groups in Northeast Brazil. Cad. Saúde Pública 2004 Jan-Fev; 20 (1): 320-8.

6 Bardin L. Análise de conteúdo. Lisboa (PT): Edições 70; 1977.

7 Monteiro M. Quem não usa camisinha: não pode dizer que ama. Campina Grande (PB): Martins Ed.; 2005.

8 Paulino ESP. Previna-se contra a AIDS: é melhor prevenir que remédio não há. Fortaleza (CE): Tupynamquim Ed.; [199-].

9 Vieira G, Carvalho G. Previna-se contraa AIDS: ela mata. Fortaleza (CE): Tupynamquim Ed.; 1996.

10 Antczak SE, Berger N, Conroy WT, Craig L, Durston S, Hanes DA et al, organizadores. Fisiopatologia básica. Riode Janeiro (RJ): Guanabara Koogan; 2005. cap.7, p. 171-184.

11 Secretaria da Saúde do Estado do Ceará, Coordenadora de Políticas e Saúde, Núcleo de Epidemiologia. AIDS: informe trimestral. Fortaleza (CE): SESA; 2006.

12 OliveiraDC, Costa TL, Gomes AMT, AcioliS, Formozo GA,HeringerA,etal.Análisedaproduçãodeconhecimento sobre o HIV/AIDS em resumos de artigos em periódicos brasileiros de enfermagem, no período de 1980 a 2005. Texto Contexto Enferm. 2006 Out-Dez; 15 (4): 654-62.

13 Galvão MTG, CerqueiraATAR, Marcondes-MachadoJ. Avaliação da qualidade de vida de mulheres com HIV/ AIDS através do HAT-QoL. Cad. Saúde Pública 2004 Jan-Fev; 20 (2): 430-7.

14 Nogueira SA, Abreu T, Oliveira R, Araújo L, Costa T, Andrade M, et al. Successful prevention of HIV transmission from mother to infant in Brazil using a multidisciplinary team approach. Brazilian Jour. Infect. Diseases $2001 \mathrm{Abr} ; 5$ (2):78-86.

15 Stefanelli MC. Comunicação com o paciente: teoria e ensino. São Paulo (SP): Robe, 1993. 